\title{
Penerapan Model Pembelajaran Demi Terwujudnya Peningkatan Kesadaran Peserta Didik Mengenai Proklamasi Kemerdekaan Indonesia
}

\author{
${ }^{1}$ Aulia Nisa Asyani, ${ }^{2}$ Siti Fatimah, ${ }^{3}$ Tuti Istiani, ${ }^{4}$ Muh. Husen Arifin \\ 1,2,3,4 Universitas Pendidikan Indonesia Kampus Cibiru \\ Jl. Pendidikan No.15, Cibiru Wetan, Cileunyi,, Bandung, Jawa Barat, 40625 \\ 1'nisaasyani@upi.edu \\ ${ }^{2}$ sitifatimah26@upi.edu \\ 3tutiistiani@upi.edu \\ ${ }^{4}$ muhusenarifin@upi.edu
}

\begin{abstract}
The background of this research is related to the development of human resources through social sciences which must be introduced to students from an early age. Of course, in the introduction of social studies, teachers must use learning models so that teaching and learning activities can be achieved in accordance with learning objectives The formulation of the problem in this research article is how a teacher can add learning related to social science. In addition, what learning models can be used by teachers in teaching social sciences. The purpose of this study is so that readers can understand various learning models that can be used in increasing students' understanding of the Proclamation of Indonesian Independence. This study uses qualitative research methods that use data types in the form of results from journal literature, books, and other scientific works as a reference for writing research. The results of this study indicate that there are several learning models that can be used by educators in teaching and learning activities about the Proclamation of Indonesian Independence.
\end{abstract}

Keywords: Learning Model, Social Studies, Human Resources, Proclamation of Indonesian Independence

ABSTRAK
Penelitian ini dilatarbelakangi terkait pengembangan sumber daya manusia melalui ilmu sosial yang harus diperkenalkan kepada peserta didik secara dini. Tentunya dalam pengenalan ilmu sosial ini guru harus menggunakan model-model pembelajaran agar kegiatan belajar mengajarnya dapat tercapai sesuai dengan tujuan pembelajaran. Rumusan masalah dalam penelitian artikel ini yaitu bagaimana cara seorang guru dalam menyampaikan pembelajaran terkait dengan ilmu sosial. Selain itu model pembelajaran apakah yang dapat digunakan oleh guru dalam mengajarkan ilmu sosial. Tujuan dari penelitian ini yaitu agar para pembaca dapat memahami banyaknya model pembelajaran yang dapat digunakan dalam meningkatkan pemahaman peserta didik tentang Proklamasi Kemerdekaan Indonesia. Penelitian ini menggunakan metode penelitian kualitatif yang menggunakan jenis data berupa hasil dari literatur jurnal, buku, serta karya tulis ilmiah lainnya sebagai referensi penulisan penelitian. Hasil penelitian ini memperlihatkan bahwa ternyata ada beberapa model pembelajaran yang dapat digunakan sang pendidik dalam kegiatan belajar mengajar tentang Proklamasi Kemerdekaan Indonesia.

Kata Kunci : Model Pembelajaran, Ilmu Sosial, Sumber Daya Manusia, Proklamasi Kemerdakaan Indonesia

\section{PENDAHULUAN}

Pembekalan, pengembangan manusia dan pengembangan sumber daya adalah cara-cara yang harus ditempuh dalam rangka mewujudkan peningkatan kualitas SDM. Melalui proses pendidikan, penciptaan sumber daya manusia berkualitas akan terwujud serta tercapai. Masalah pendidikan merupakan masalah yang sangat kompleks yang membutuhkan kematangan dan perencanaan yang tepat. Pendidikan yang dilakukan oleh para guru ketika belajar terutama di sekolah, pendidikan harus bisa menyediakan dan meningkatkan wawasan yang luas, sikap positif, dan keterampilan sebagai bekal dalam kehidupan mereka. Guru memiliki peran yang sangat besar untuk menciptakan perilaku 
peserta didik dan perkembangan sikapnya. Profesionalisme guru sangat dituntut untuk pencapaian tujuan pendidikan yang diharapkan, yaitu: demi terwujudnya kecerdasan hidup bangsa. Guru adalah seorang pendidik profesional dengan tugas pokok mendidik, mengajar, mengarahkan, membina, melatih, mengapresiasi, dan mengevaluasi siswa di PAUD pada pendidikan formal, pendidikan dasar, dan pendidikan menengah. Salah satu mata pelajaran yang wajib dikuasai oleh guru SD adalah ilmuilmu sosial.

Guru dalam mengajar ilmu sosial harus dapat mendorong siswa untuk mengembangkan pengetahuan mereka, pemahaman, dan keterampilan analitis terhadap lingkungan sosial kondisi masyarakat pada masa sekarang dan masa depan. Menjadi guru sosial yang baik harus memiliki minimum dasar pembelajaran dalam mempelajari ilmu sosial. Karena mempelajari sosial di sekolah dasar tidak berarti mengajar ilmu social disiplin, itu mengajarkan konsep-konsep ilmu sosial yang penting untuk membentuk peserta didik menjadi warga negara yang baik. Dalam belajar, siswa perlu terlibat secara aktif untuk mendapatkan motivasi dan ikuti setiap prosesnya. Jika siswa mengikuti aktivitas belajar secara pasif, kegiatan belajar tidak akan berjalan dengan optimal. Jika siswa tidak berperan dengan aktif ketika kegiatan belajar mengajar, maka pembelajaran tersebut tidak akan berhasil. Hal tersebut disebabkan oleh sifat pembelajaran yang melibatkan pemikiran dan aktif mengikuti setiap proses belajar.

Sumber daya manusia ini perlu ditingkatkan kualitasnya. Solusi agar mampu meningkatkan kualitasnya yaitu oleh pendidikan. Pendidikan menentukan keberhasilan dan kesuksesan setiap manusia. Pada hakikatnya, manusia tidak terlepas dari yang namanya interaksi pada lingkungan sosial. Oleh karena itu, manusia berkaitan erat dengan sosial. Dengan adanya ilmu social ini, setiap insan bisa memahami apa hakikat dari ilmu sosial tersebut. Terutama, untuk peserta didik di sekolah dasar. Peserta didik perlu memahami apa hakikat dari ilmu sosial tersebut. Pembelajaran di sekolah menuntut guru untuk mendidik secara kreatif agar dapat menyampaikan suatu materi sosial kepada peserta didik agar tujuan pembelajaran tersebut tercapai dan dapat dilakukan secara maksimal. Namun pada pengimplementasiannya, kegiatan pembelajaran ilmu sosial seringkali dianggap sebagai suatu pembelajaran yang membosankan. Seperti yang kita ketahui, bahwa ilmu sosial mencakup beberapa sub ilmu yaitu sosiologi, ekonomi, sejarah, dan geografi. Dengan sub ilmu sosial ini, dianggap sebagai sesuatu yang tidak menarik dan terkadang dianggap sebagai sesuatu hal yang mudah. Padahal, dalam kenyataannya, peserta didik perlu memahami betul ilmu sosial dan bagaimana cara mengimplementasikannya dalam kehidupan sehari-hari.

\section{KAJIAN PUSTAKA}

Pendidikan menyampaikan suatu bekal pengetahuan pada peserta didik dalam suatu bidang eksklusif yang dapat menyampaikan akibat positif buat mencapai tujuan pendidikan yang optimal. Salah satu pengetahuan yang diterima sang peserta didik ialah ilmu pengetahuan sosial. Pengertian IPS menjadi pendekatan interdisipliner asal pelajaran ilmu-ilmu sosial, seperti sosiologi, antropologi budaya, spikologi social, sejarah, geografi, ekonomi, ilmu politik, serta sebagainya.

Pembelajaran IPS bertujuan membina murid sebagai warga negara yang baik, yang mempunyai pengetahuan, keterampilan serta kepedulian sosial yang bermanfaat bagi dirinya sendiri dan bagi warga serta negara.

Proklamasi kemerdekaan ialah sebuah deklarasi pada semua warga serta negara-negara di global akan adanya kemerdekaan. Proklamasi kemerdekaan menaikkan taraf kehidupan Bangsa Indonesia buat sederajat menggunakan bangsa-bangsa lain di global. [1] Diperoleh bahwa proklamasi bagi bangsa Indonesia sendiri merupakan suatu pernyataan suatu bangsa untuk melepaskan dirina dari belenggu penjajahan, serta dapat membentuk Negara Republik Indonesia yang bebas, independen serta berkuasa secara penuh.

Dalam pendidikan sendiri terdapat materi proklamasi yang dapat diajarkan seorang pendidik kepada peserta didiknya. Beberapa pendidik memerlukan cara untuk dapat membantu mereka menyampaikan materi tersebut kepada peserta didik. Salah satu cara tersebut yaitu dengan penerapan model yang tepat agar dapat mempermudah pendidik. Diantaranya yaitu penerapan beberapa model seperti yaitu diantaranya penerapan model pembelajaran Teams Games Tournament, Jigsaw, Show and Tell, Mind Mapping dan Numbered Head Together. Bila dilihat [2]"Model Pembelajaran Kooperatif Tipe Numbered Head Together (NHT) merupakan macam model kooperatif dengan 
struktur elementer nan terdiri dari empat tahapan kemudian digunakan dalam memeriksa kembali fakta, serta informasi dasar yang berfungsi mengatur interaksi siswa." Dengan kata lain dapat didapat bahwa NHT merupakan suatu model pembelajaran kooperatif serta didalamnya ditemukan siswa bervariatif supaya mampu mempertanggung jawabkan atas tugas yang diberikan terhadap kelompoknya. Selain itu terdapat juga [3] Model pembelajaran Jigsaw adal suatu tipe pembelajaran kooperatif yang terdiri dari beberapa anggota dalam satu kelompok yang bertanggung jawab atas penguasaan bagian materi belajar serta mampu mengajarkan bagian tersebut kepada anggota lain dalam kelompoknya. Setelah jigsaw terdapat juga [4] Show and Tell dengan kegiatan menunjuk sesuatu kepada audience dan menjelaskan atau mendeskripsikan sesuatu. Model ini dapat dimanfaatkan untuk tiga ranah, yaitu berbicara, bermain serta bercerita. Kemudian terdapat juga [5] model Numbered Head Together (NHT) yang merupakan salah satu tipe pembelajaran kooperatif yang menekankan pada struktur khusus yang dirancang untuk mempengaruhi pola interaksi siswa dan memiliki tujuan untuk meningkatkan penguasaan akademik. Dan terakhir terdapat [6] Team Games Tournament, yaitu suatu pembelajaran dimana setelah kehadiran guru, siswa pindah ke kelompoknya masing-masing untuk saling membantu menjawab pertanyaan-pertanyaan dari materi yang diberikan. Setiap siswa akan bertemu pada meja tournamen untuk berlomba dan menjawab satu pertanyaan yang sama yang telah dijawab bersama-sama dalam kelompoknya. Dengan kesempatan ini setiap siswa akan memiliki kesempatan untuk menyumbangkan skor sebanyak-banyaknya untuk kelompok mereka.

\section{METODE PENELITIAN}

Penggunaan metode penelitian ini ketika penyusunan penulisan artikel yaitu metode kualitatif. Metode yang diterapkan dalam penulisan penelitian yang digunakan dalam penyusunan artikel ini menggunakan metode kualitatif. Adapun bentuk penulisan yang digunakan pada artikel ini menggunakan jenis data berupa hasil dari literatur yang diperoleh melalui buku-buku serta jurnaljurnal penelitian ilmiah yang didapat, dimana dalam pembahasan karya tulis ilmiah tersebut berhubungan dengan materi dan pembahasan pada artikel yang disusun yang berhubungan dengan penerapan model pembelajaran untuk meningkatkan pemahaman peserta didik mengenai proklamasi kemerdekaan Indonesia. Adapun data-data yang diperoleh guna penyusunan artikel ini diperoleh melalui hasil literatur dari beberapa karya tulis ilmiah yang bersumber dari buku-buku serta sumber lain melalui proses literatur dari jurnal-jurnal penelitian ilmiah yang diperoleh, kemudian data yang diperoleh melalui hasil literatur ini akan dianalisis menggunakan teknik pendekatan studi deskriptif.

\section{HASIL DAN PEMBAHASAN}

Hasil yang diperoleh melalui pengumpulan data yang telah dilakukan dengan teknik literatur dari beberapa karya tulis ilmiah mengenai penerapan model pembelajaran apa saja yang dapat digunakan untuk meningkatkan pemahaman peserta didik mengenai proklamasi kemerdekaan indonesia. Sehingga terdapat beberapa hasil yang diperoleh diantaranya yaitu terdapat beberapa penerapan model pembelajaran guna meningkatkan pemahaman peserta didik dalam materi mengenai proklamasi kemerdekaan Indonesi, yaitu diantaranya penerapan model pembelajaran Teams Games Tournament, Jigsaw, Show and Tell, Mind Mapping dan Numbered Head Together.

1. Model Pembelajaran Teams Games Tournament

Pembelajaran yang akan ditelaah kali ini menyangkut salahsatu mata pelajaran yang ada, yaitu mata pelajaran Ilmu Pengetahuan Sosial dengan materi pokok yang diangkat mengenai proklamasi kemerdekaan Indonesia. Model pembelajaran pertama yang dapat kita terapkan dalam meningkatkan pemahaman siswa mengenai materi proklamasi kemerdekaan Indonesia yaitu Teams Games Tournament. [7] Diperoleh bahwa model pembelajaran Teams Games Tournament merupakan suatu model pembelajaran yang melibatkan aktivitas siswa yang bertujuan untuk memproleh pengetahuan dan pemahaman baru dari interaksi yang mereka lakukan dengan teman-temannya dan didalam model tersebut mengandung unsur permainan, sehingga siswa akan lebih berantusias dalam pelaksanaan pembelajarannya. Selain itu juga hasil dalam penelitiannya didapat bahwa dalam pelaksanaan model Teams Games Tournament pada materi proklamasi kemerdekaan Indonesia yang dilaksanakan di Kelas V SD Negeri 1 Sindang Rasa ini mendapatkan hasil perubahan yang signifikan yang 
berpengaruh pada meningkatnya hasil pemahaman siswa pada materi proklamasi kemerdekaan Indonesia.

Proses yang dilakukan dalam model Teams Games Tournament ini diawali denhgan menguji pemahaman awal siswa dengan melakukan pretest terlebih dahulu sebelum pemberian pembelajaran. Kemudian dilanjutkan dengan pelaksanaan menggunakan Teams Games Tournament dan kemudian dilakukan posttest pada akhir pembelajarannya. Dari hasil tersebut diperoleh bahwa terdapat perubahan yang sangat tinggi setelah diberikan perlakuan dengan hasil yang didapat dari pretest dengan rata-rata yang didapat yaitu 8,69 dengan kategori sedang dan hasil yang didapat dari posttest mendapat peningkatan dengan rata-rata 12,39 dengan kategori sangat tinggi. Sehingga didapatkan bahwa model Teams Games Tournament ini dapat membantu meningkatkan pemahaman siswa mengenai proklamasi kemerdekan Indonesiandikarenakan model ini dirancang dengan pembelajarannya yang menyenangkan yang membuat siswa dapat jadi lebih aktif dalam mengikuti setiap kegiatan pembelajarannya.

Model Teams Games Tourname [8] dengan teknikn pengumpulan data meliputi teknik tes dan teknik non tes. Selain itu didapatkan juga bahwa terdapat peningkatan keterampilan guru dalam penerapan model ini. Dimana keterampilan guru siklus I memperoleh skor 25 dengan kategori cukup dan keterampilan guru siklus II memperoleh skor 32 dengan kategori baik, begitu juga dengan kemampuan siswanya. Sehingga diperoleh bahwa penerapan model pembelajaran Teams Games Tourname ini sangat efektif digunakan untuk membantu guru dalam penyampaian pembelajaran IPS.

\section{Model Pembelajaran Jigsaw}

Selain Teams Games Tournament, terdapat pula model pembelajaran Jigsaw yang dapat membantu siswa dalam meningkatkan pemahaman mengenai proklamasi kemerdekaan Indonesia. [9]Diperoleh bahwa keefektifan penggunaan pengembangan model pembelajaran jigsaw dengan berbantuan CD interaktif terhadap hasil belajar peserta didik pada pemahamannya mengenain pokok bahasan proklamasi kemerdekaan Indonesia diketahui dari hasil validasi ahli dan juga uji coba kelas terbatas. Dalam penelitiannya dimana terdapat perbedaan yang signifikan atas prestasi belajar yang dilihat dari pemahaman peserta didik antara kelompok eksperimen dengan kelompok kontrol. Respon guru serta siswa pada model pembelajaran Jigsaw dengan bantuan CD interaktif juga ditemukan beberapa variatif yang signifikan. Dengan kelompok eksperimen yang menggunakan model pembelajaran yang memiliki respons positif terhadap kegiatan pembelajaran yang dilakukannya. Sementara itu aktifitas siswa pada model pembelajaran Jigsaw dengan bantuan CD ini sangat terbantu, sehingga aktivitas belajar pada kelas eksperimenpun terdapat peningkatan kelas dibandingkan dengan kelas kontrol. Sehingga dari hasil tersebut dapat disimpulkan bahwa penerapan dengan pengembangan model pembelajaran Jigsaw menggunakan media bantu berupa CD interaktif ini sudah memenuhi kriteria dan dapat diujicobakan lebih luas lagi.

Selain penelitian diatas terdapat juga penelitian yang dilakukan di SD Negeri 01 Gondang Pamalang pada siswa kelas V [10] dengan hasil tes awal sebesar 68,73 dengan presentase belajar siswa yang didapat ialah $58,54 \%$ dan hasil tes akhir memperoleh nilai rata-rata 79,46 dengan presentase ketuntasan belajar siswa 78,05\%. Selain itu juga presentase nilai performansi guru menjadi 76,88 dengan kriteria nilai B yang kemudian meningkat menjadi 84,58 dengan kriteria nilai AB. Sehingga dapat disimpulkan bahwa dengan penerapan model jigsaw ini dapat meningkatkan aktivitas belajar, hasil belajar siswa serta performansi guru kelas V SD Negeri 01 Gondang Pemalang.

\section{Model Pembelajaran Show and Tell}

Dalam pembelajaran melalui materi proklamasi kemerdekaan Indonesia, kita dapat menerapkan model pembelajaran lain, diantaranya yaitu model pembelajaran Show and Tell. [11] Berdasarkan hasil penelitian yang dilakukan, diperoleh bahwa model pembelajaran ini memiliki banyak kelebihan yang dapat membantu meningkatkan kemampuan siswa bahkan dalam berkomunikasi, hasil belajar, serta dapat melahirkan siswa yang aktif ketika mengikuti pembelajaran. Dimana model Show and 
Tell ini sangat baik untuk mengungkapkan perasaan dan keinginan anak, dimana teori dapat diterima dan sesuai dengan hasil penelitian yang diperoleh.

[11] Dalam penelitian diperoleh bahwa hasil belajar peserta didik pada kelas yang menerapkan model Show and Tell lebih baik dibandingkan dengan model konvensional. Dengan data hasil penelitian yang diperoleh menggunakan observasi pada kelas eksperimen dan kelas kontrol pada peserta didik kelas VA dan VB SD Negeri Babalan yang dibagi menjadi kelas eksperimen yang menerapkan model Show and Tell dan kelas kontrol yang menggunakan model konversal dengan dua data yang diuji yaitu keterampilan berkomunikasi serta hasil belajar siswa yang dilakukan dengan cara psttes dengan pemerolehan kelas eksperimen sebesar 85,03 dan kelas kontrol sebesat 75, 62 sehingga didapat bahwa hasil posttes kelas eksperimen lebih tinggi dibandingkan kelas kontrol. Selain itu juga terdapat pemerolehan hasil data yang diuji menggunakan uji t dua sampel, dengan data awal yang diperoleh yaitu $\mathrm{dk}=44$ ( $\operatorname{taraf}$ kesalahan $5 \%$ ) dan diperoleh nilai $\mathrm{t}_{\text {tabel }}=2,02$. Hasil perhitungan pada uji $\mathrm{t}$ diperoleh nilai $t_{\text {hitung }}=5,347$. Dengan $t_{\text {hitung }}>t_{\text {tabel }}$ yaitu 5,347>2,02 maka dapat disimpulkan bahwa keterampilan siswa dalam berkomunikasi menggunakan model pembelajaran Show and Tell ini lebih baik dibandingkan dengan model konvensional. Berdasarkan hasil penelitian tersebut, maka dapat diperoleh kesimpulan bahwa model pembelajaran Show and Tell ini dapat meningkatkan kemamuan berkomunikasi, serta hasil belajar membentuk siswa bertambah tinggi sesudah diberikan pembelajaran dengan model pembelajaran Show and Tell.

\section{Model Mind Mapping}

Dari hasil penelitian yang dilakukan [12] diperoleh bahwasanya model Mind Mapping memberikan pengaruh terhadap hasil belajar siswa pada materi sekitar proklamasi kemerdekaan peserta didik kelas V SD Negeri 2 Siluman Kecamatan Cibeureum Kota Tasikmalaya. Diperkuat dengan adanya proses pengumpulan data yang diperoleh melalui skor pretest dan posttest untuk kelas eksperimen dan kelas kontrol dengan uji perbedaan rata-rata yang dilakukan dengan uji statistic t, dengan taraf signifikan $\alpha=0,05$. Kemudian diadakan pengujian lainnya dengan hasil akhir data yang diperoleh keseluruhan menunjukkan terdapat pengaruh yang signifikan dari hasil belajar siswa di kelas eksperimen. Melalui perhitungan uji t independent Sample Test diberoleh hasil sig (2-tailed) yaitu 0.000 yang berarti sig $<0,05$. Selain itu juga terdapat data hasil normal gain yang didapat dari kelas kontrol dengan rata-rata 0,42 dengan kategori kurang efektif, dan nilai hasil rata-rata kelas eksperimen dengan menerapkan model Mind Mapping sebesar 0,71 yang menandakan ditemukannya variatif yang signifikan antar nilai normal gain hasil belajar siswa kelas kontrol serta ekperimen. Sehingga didapat bahwa model Mind Mapping ini dapat meningkatkan pemahaman siswa mengenai materi proklamasi kemerdekaan Indonesia.

Selain penelitian diatas, didapat juga beberapa penelitian lain yang menggunakan model yang sama dengan memperoleh hasil yang dapat meningkatkan keaktifan, pemahaman siswa serta performan guru. [13] dalam penelitian yang dilakukan di SD Negeri Sidapurna 01 Kabupaten Tegal, diperoleh hasil uji hipotesis pertama menggunakan independent samples $t$ test, diperoleh nilai $t$ hitung $>t$ tabel $(2,557>2,024)$, sehingga H0 ditolak. Dan uji hipotesis kedua menggunakan one sample $t$ test, diperoleh nilai t hitung $>\mathrm{t}$ tabel $(3,952>2,080)$ sehingga $\mathrm{H} 0$ ditolak.

\section{Model Pembelajaran Kooperatif tipe Numbered Head Together}

Dalam hasil penelitian yang dilakukan [2] diperoleh bahwa model NHT sangat efektif dalam melatih siswa dalam menjadikannya sebagai seseorang yang kritis. Terdapat beberapa tahapan yang dilakukan, diantaranya pada tahap heads together ini siswa akan diberikan kesempatan untuk berfikir sevara individu sebelum melaksanakan kegiatan berpikir bersama dalam memecahkan masalah, membuat keputusan serta menganalisa tentang permasalahan yang diberikan oleh guru. Setelah kegiatan berpikir secara individu, siswa akan dihadapkan dengan tahap berpikir bersama dengan pemikiran teman-temannya yang variatif dan secara tidak langsung, peserta didik akan dituntut untuk menyeleksi pemikiran yang dianggap paling benar. Dalam tahap menyeleksi inilah peserta didik akan 
berusaha mengevaluasi secara sistematis bobot-bobot pendapat, sehingga kondisi ini secara langsung akan otomatis mengasah dan membangun karakter pemikiran kritis pada peserta didik.

Dalam penelitian yang diperoleh berdasatkan hasil analisis dari dua macam kelas yang menjadi kelas eksperimen dan kelas kontrol dengan pemerolehan nilai rata-rata pada pretest kelas kontrol adalah 44,25 dan kelas eksperimen sebesar 40,10 dengan selisih 4,15 dan postest kelas kontrol sebesar 72,20 dan kelas eksperimen sebesar 76,80 dengan selisih 4,6. Dapat terlihat kemajuan melalui soal postesst yang dilakukan pada siswa kelas ekperimen yang mendapatkan pembelajaran dengan model NHT, mampu menjawab soal dengan kritis, logis dan sistematis. Selain penelitian diata, didapat juga penelitian lain dengan hasil [14] bahwa terdapat pengaruh pada model ini terhadap hasil belajar di kelas V SD Negeri 38 Pontianak Utara, dibuktikan dengan hasil uji-t pada taraf $=5 \%$ dan dk 44 sehingga diperoleh $t$ hitung 3,24 dan yt tabel 1,68 . Karena $t$ hitung $(3,24)>t$ tabel $(1,68)$ maka Ha diterima dan dikatakan signifikan. Selain itu besar pengaruh penerapan model ini terhadap hasil belajar adalah sebesar 0,81 dengan kategori tinggi. Dari hasil penelitian lain juga didapat bahwa [15] terdapat peningkatan hasil belajar siswa pada setiap pertemuannya kelas V di SD Negeri Teluk Tiram 1 dengan peningkatan sebesar $90,90 \%$.

\section{KESIMPULAN DAN SARAN}

Terdapat macam-macam penerapan model pembelajaran yang bisa digunakan dalam setiap kegiatan pembelajaran. Model ini mampu dilakukan pada setiap jenjang pendidikan dan dapat disesuaikan dengan karakteristik siswa guna meningkatkan pemaham dan kualitas belajar peserta didik. Maka dari itu, guru harus mampu memilih dan menentukan model pembelajaran yang tepat digunakan untuk meningkatkan kualitas belajar serta meningkatkan pemahaman siswa dalam suatu materi yang akan disampaikan oleh guru. Salah satunya dalam materi siswa SD kelas V yang membahas mengenai Peristiwa Proklamasi Kemerdekaan Indonesia. Dalam penelitian kali ini didapatkan bahwa guru tidak hanya dapat memanfaatkan satu model pembelajaran yang sama dalam setiap materi pembelajaran yang disampaikan, melainkan guru dapat menggunakan macam-macam model pembelajaran yang dapat disesuaikan dengan karakteristik siswanya dalam meningkatkan pemahaman serta hasil belajar siswa yang dapat digunakan dalam setiap kegiatan pembelajaran. Macam-macam model pembelajaran yang dapat digunakan terutama dalam materi pokok Peristiwa Proklamasi Kemerdekaan Indonesia, diantaranya yaitu dengan Model Pembelajaran Teams Games Tournament, Model Pembelajaran Jigsaw, Model Pembelajaran Show and Tell, Model Pembelajaran Mind Mapping dan Model Pembelajaran Numbered Head Together. Dengan beberapa penelitian yang diperoleh berkaitan dengan penerapan model-model pembelajaran yang diterapkan tersebut dalam materi Proklamasi Keemerdekaan Indonesia dengan pembagian kelas kedalam dua macam, yaitu kelas kontrol dengan model pembelajaran konversal dan kelas eksperimen dengan penerapanpenerapan model pembelajaran Teams Games Tournament, Jigsaw, Show and Tell, Mind Mapping dan Numbered Head Together berhasil memberikan banyak sekali peningkatan yang signifikan dalam setiap hasil pembelajaran serta pemahamannya yang diperoleh dari hasil ujian pretest dan posttest. 


\section{DAFTAR PUSTAKA}

[1] A. B. Satia, C. N. Rimayani, and H. Nuraini, "Sejarah Ketatanegaraan Pasca Proklamasi Kemerdekaan 17 Agustus 1945 Sampai 5 Juli 1959 Di Indonesia," Mimb. Yustitia, vol. 3, no. 1, pp. 89-104, 2019, doi: 10.52166/mimbar.v3i1.1864.

[2] F. A. Febrianti, "Implementasi Model Pembelajaran Kooperatif Tipe Numbered Head Together (NHT) Dalam Meningkatkan Kemampuan Berpikir Kritis Siswa Pada Pembelajaran IPS,” J. Civ. Soc. Stud., vol. 3, no. 2, pp. 42-52, 2020, doi: 10.31980/2655-7304.v3i2.696.

[3] P. Ips, D. I. Kelas, S. D. N. Citamiang, and S. D. N. Citamiang, "Model Jigsaw Dalam Meningkatkan Hasil Belajar Siswa Pada," pp. 34-41.

[4] C. Suarsih, "Upaya Meningkatkan Keterampilan Berbicara Siswa Dengan Menerapkan Metode Show and Tell Pada Pembelajaran Bahasa dan Sastra Indonesia Penelitian Tindakan Kelas Pada Siswa Kelas II di SD Negeri Sumurbarang Kecamatan Cibogo Kabupaten Subang Tahun Pelajaran 2," J. Penelit. Guru FKIP Univ. Subang, vol. 1, no. 1, p. 5, 2018.

[5] Y. F. Surya, "Penerapan Model Numbered Head Together Untuk Meningkatkan Hasil Belajar Ips Kelas Iv Sd,” J. Basicedu, vol. 2, no. 1, pp. 135-139, 2018, doi: 10.31004/basicedu.v2i1.34.

[6] I. Irviana, "Pengaruh Model Pembelajaran Team Games Tournament Terhadap Hasil Belajar Ips Siswa Sd," J. Educ. Sci. Technol., vol. 2, no. 1, p. 56, 2016, doi: 10.26858/est.v2i1.2041.

[7] I. Selviani and N. Ganda, "Pengaruh Model Teams Games Tournament terhadap Pemahaman Materi Peristiwa Sekitar Proklamasi Kemerdekaan pada Pembelajaran IPS," PEDADIDAKTIKA J. Ilm. Pendidik. Guru Sekol. Dasar, vol. 5, no. 1, pp. 242-251, 2018.

[8] J. Pendidikan, G. Sekolah, F. I. Pendidikan, and U. N. Semarang, "Keefektifan model pembelajaran teams games tournament (tgt) berbantuan media audiovisual terhadap hasil belajar ips kelas v sdn gugus mawar magelang," 2019.

[9] F. Aristya and S. Hadi, "Pengembangan Model Pembelajaran Jigsaw Berbantuan CD Interaktif pada Pokok Bahasan Proklamasi," 2016.

[10] A. S. Indah, "Peningkatan Pembelajaran Materi Peristiwa Sekitar Proklamasi Melalui Model Jigsaw," J. Elem. Educ., vol. 2, no. 2, pp. 1-5, 2013.

[11] I. Arviani and K. Fajriyah, "Keefektifan Model Show and Tell untuk Meningkatkan Keterampilan Berkomunikasi pada Materi Proklamasi Kemerdekaan Siswa Kelas V SD Negeri Babalan," Al Ibtida J. Pendidik. Guru MI, vol. 5, no. 1, p. 1, 2018, doi: 10.24235/al.ibtida.snj.v5i1.1877.

[12] S. H. Anandita Cyntisa Dwi Putri, Sumardi, "Pengaruh Model Mind Mapping terhadap Hasil Belajar Siswa pada Materi Peristiwa Sekitar Proklamasi Kemerdekaan Ilmu Pengetahuan Sosial di Sekolah Dasar," vol. 5, no. 1, pp. 118-125, 2018.

[13] T. Hasil and B. Ips, "Keefektifan Model Mind Mapping Terhadap Hasil Belajar Ips," J. Elem. Educ., vol. 3, no. 2, pp. 64-70, 2014.

[14] S. Halidjah, M. Asran, P. Studi, P. Guru, and S. Dasar, "PENGARUH NUMBERED HEAD TOGETHER TERHADAP," pp. 1-8, 2007.

[15] M. Saleh, "Implementasi Kombinasi Model PBL, NHT , dan Make A Match untuk Meningkatkan Aktivitas dan Hasil Belajar Siswa pada Pembelajaran IPS," vol. 4, no. 2, pp. 198-210, 2021. 